\title{
REFLEXÕES ACERCA DO COTIDIANO DE MULHERES TRABALHADORAS RURAIS "BOIAS-FRIAS" NA CULTURA CANAVIEIRA DO INTERIOR PAULISTA
}

\author{
REFLECTIONS ON THE DAILY LIFE OF "BOIA-FRIAS" RURAL \\ WOMEN WORKERS ON THE SUGAR CANE CULTIVATIONIN SÃO \\ PAULO STATE COUNTRYSIDE
}

DOI: http//dx.doi.org/10.15448/2178-3748.2017.1.26784

\author{
Antonio Alves Bezerra \\ Docente do curso de História e do PPGH da UFAL/ICHCA \\ Coordenador do PIBID/História - UFAL \\ antonio.alves@ichca.ufal.br
}

\begin{abstract}
RESUMO: Este artigo refleteacerca das experiências de lutas vivenciadas por mulheres trabalhadoras rurais "boias-frias"que atuaram na cultura canavieira no oeste paulista,nos primórdios do século XXI. Por meio da História Oral e dos estudos de gênero enquanto categoria de análise, evidencia a maneira pelas quais essas trabalhadoras percebem e explicam a sua segregação no mundo do trabalho e a exploração do capitalismo implementado em larga escala no setor sucroalcooleiro a partir dos anos de 1960. Além disso, o artigo discorre sobre os registros, nas memórias dessas mulheres, das transformações no campo, e sobre suas perspectivas de futuro no universo do trabalho rural em constante modificação. Utilizando essa metodologia de pesquisa, são explicitadas algumas das interfaces que marcaram as experiências de vida e de lutas das trabalhadoras rurais cortadoras decana das Usinas Nova América e Maracaí (complexos sucroalcooleiros alocados na região de Assis, interior paulista).As reflexões do artigo partem da análise das falas das trabalhadoras,entrevistadas à luz de referenciais teóricos, em busca de se compreender as interfaces de suas experiências de lutas e sobrevivência,tanto no campo dos canaviais, quanto no espaço do lar, problematizando os diferentes contextos doseu cotidiano,com base no reconhecimento de que são sujeitos sociais e históricos.
\end{abstract}

PALAVRAS-CHAVE:Trabalhadoras rurais. Canavial. História Oral.

ABSTRACT:This paper reflects on the experiences of struggles by "boia-frias" rural women who worked on the sugar cane cultivation in São Paulo state western region during the early 21 st century. Using Oral History and gender studies as analysis categories, the way through which worker women understand and explain their segregation from the world of work and the capitalistic exploitation implemented in large scale on the sugar-alcohol sector since the 1960s is shown. In addition, the paper discusses the records of country side transformation in the memories of these women and their future perspectives on the universe of rural work under constant shift. Using this research methodology, some of the interfaces that marked the struggles and life experiences of the rural women that cut sugarcane in Nova América and Maracaí refineries (sugar-alcohol plants located in the region of Assis, SP) are highlighted. The reflections of this paper start from the analysis of the worker's own words, interviewed through the theoretical references, seeking to understand the interfaces of their struggle and survival experiences, at home as well as in the sugarcane fields, problematizing the different contexts of their daily life based on the acknowledgment that they are social and historical subjects.

KEYWORDS: Rural women workers. Sugarcane Fields. Oral History. 


\section{A mulher trabalhadora rural "boia-fria": cotidiano e poder}

O presente artigo busca discutir algumas interfaces do universo das mulheres trabalhadoras rurais segundo seus próprios olhares, expressando, assim, os seus pontos de vista acerca das mudanças e permanências que se fazem presentes no cotidiano. Nesse ínterim, o artigo discute acerca de suas percepções no que se refere ao processo tecnológico implantado na área rural, assim como a que poderes essas trabalhadoras da cana foram submetidas para que permaneçam nesses reduzidos postos de trabalho.

Para tanto, a utilização da História Oral enquanto "método de pesquisa que produz uma fonte especial, tem se revelado um instrumento importante no sentido de possibilitar preservação e melhor compreensão da memória coletiva e dos processos de construção de identidades de grupos ou indivíduos nas sociedades" (FERREIRA; FRANCO, 2013, p.142). Tivemos a oportunidade de contar com entrevistas/relatos de trabalhadores rurais do eito da cana das usinas Nova América e Maracaí, ambas pertencentes ao grupo Resende Barbosa.Neste artigo, especificamente, são utilizados os relatos ${ }^{1}$ de três mulheres e um homem da região de Assis (SP). Em face disso, nos deparamos com informações pertinentes e que, ao se intercruzarem com os estudos "delimitados à categoria/perspectiva de gênero" (MATOS, 2013, p.8), evidenciam muitas contradições, além de histórias de submissão feminina nos canaviais, lutas, resistências e embates políticos.

Este estudo se pauta em reflexões legadas pelos estudos de gênero enquanto categoria de análise ${ }^{2}$,ao dialogar com o cotidiano das mulheres trabalhadoras rurais "boias-frias" no oeste do estado de São Paulo. Assim, partimos da premissa de pontuar suas práticas e representações dentro e fora dos espaços canavieiros, buscando refletir sobre as falas dessas mulheres, que mostraram a sua forma de agir e de se portar face aos mais diversos conflitos iminentes na área rural ou urbana.

Segundo a perspectiva dos estudos de gênero desenvolvidos a partir dos anos de 1970 e 1980, houve um crescente avanço no que se refere às investigações cuja centralidade temática se circunscreve em torno das mais variadas formas de trabalho feminino no Brasil. Notamos, dessa maneira, que "no âmbito da temática do trabalho, além de resgatar o cotidiano fabril, lutas e greves, ação-exclusão nos espaços dos sindicatos, procurou-se

\footnotetext{
${ }^{1}$ A coleta, assim como a análise dos dados obtidos com as entrevistas,pautou-se nas reflexões de: THOMSON, A. (1997); Portelli(1997);Montenegro(1994); Janotti, (1993); Amado(1996); Amado(1995).

2 As publicações a respeito da atuação das mulheres são vastas, sendo este terreno considerado fecundo à pesquisa histórica. Os pesquisadores desta temática têm procurado ampliar o debate sobre as mulheres, trazendoas cada vez mais para o centro das discussões. Dentre os referenciais teóricos que discutem gênero enquanto categoria de análise, deve-se destacar os trabalhos de Saffioti (1981), Scott (1990) e Matos (2013).
} 
recuperar as múltiplas estratégias e resistências criadas e recriadas no cotidiano" feminino (MATOS, 2013, pp.6-7). Posto isso, dialogamos com a perspectiva de gênero no sentido de compreendermos as práticas e representações tecidas ao longo das trajetórias das mulheres trabalhadoras rurais:

A mulher que levanta cedo no sábado, que roça o dia inteiro, volta pra casa, faz comida. No domingo, acorda cedo e luta o dia inteiro. Então você vê: o ano tem 365 dias. Calcula o ano inteiro: a mulher trabalhou um ano ou trabalhou dois num só? A mulher só tem direito só naquela hora que deita, nove horas a que deita mais cedo, a que deita mais tarde é dez horas. A que levanta mais cedo é três horas, a outra quatro, quatro e meia. (PEREIRA, 2002, p. 57).

O trecho exemplifica bem o cotidiano da mulher "boia-fria" nos canaviais de todo o território brasileiro. Notadamente, tal prática não se restringe apenas aos canaviais do estado de São Paulo; pelo contrário, se faz presente na vida de centenas de mulheres trabalhadoras que, na falta de outras oportunidades nos setores rurais e urbanos, encontram no canavial uma forma de trabalho árduo para seu sustento e que, muitas vezes, ainda se revelam como as únicas responsáveis pelo sustento de toda a família.

Podemos observar que os dias das mulheres trabalhadoras rurais "boias-frias" são recheados de atividades extras no mesmo espaço, delimitando-se apenas no eixo campocidade/canavial-residência. Em suas falas, essas mulheres revelam que se levantam muito cedo para preparar a comida levada para o eito. Além disso, realizam outras atividades, tais como deixar a comida pronta para os filhos e lavar as louças e roupas, com o objetivo de não sobrecarregar o domingo ou a noite, quando regressam da jornada de trabalho.Assim,

As mulheres não vivenciavam, como os homens, a polarização entre tempo de trabalho e de não trabalho, mas enfrentavam a rotina dos afazeres domésticos e do trabalho domiciliar. Seu tempo era modelado pelo dos outros; seus horários eram os do marido, dos filhos, do patrão, do mercado, da costura e dos bordados. O tempo das mulheres caracterizava-se pela fragmentação e superposição de tarefas, porém era variado e relativamente autônomo, situando-se em um polo oposto ao tempo do universo fabril. (MATOS, 2002, p. 95).

Corroborando as reflexões apontadas por Matos (2002), torna-se perceptível nas reflexões de Thompson (1998). Este indica que, mesmo em épocas distantes do tempo presente $^{3}$, o trabalho mais intenso e com tempo prolongado tem sido o das mulheres que trabalham na economia rural. Segundo Thompson, "parte desse trabalho - especialmente o

\footnotetext{
${ }^{3}$ Sobre a história do presente, recomenda-se a leitura da obra História do Tempo Presente (FERREIRA; DELGADO, 2014).
} 
cuidado com os bebês - era o mais orientado pelas tarefas. Outra parte se dava nos campos, de onde ela retornava para novas tarefas domésticas" (THOMPSON, 1998, p. 287).O autor traz, em um dos relatos presentes em seu estudo, as interfaces do cotidiano dessas mulheres trabalhadoras, diferenciando de forma singular as atividades laborais desenvolvidas por homens e mulheres:

[...] Quando chegamos em casa, ai de nós! Vemos que nosso trabalho mal começou; tantas coisas exigem a nossa atenção, tivéssemos dez mãos, nós as usaríamos todas. Depois de pôr as crianças na cama, com o maior carinho preparamos tudo para a volta dos homens ao lar: eles jantam e vão para a cama sem demora, e descansam bem até o dia seguinte; enquanto nós, ai! Só podemos ter um pouco de sono, porque os filhos teimosos choram e gritam [...] em todo trabalho temos nossa devida parte; e desde o tempo em que a colheita se inicia até o trigo ser cortado e armazenado, todos os dias, nossa labuta é tão extrema que quase nunca há tempo para sonhar (THOMPSON: 1998, p.287-288).

Por esse viés, percebe-se que as práticas e experiências de lutas por sobrevivência das mulheres e homens, de uma forma em geral, configuram-se como "uma categoria que, por mais imperfeita que sejam, tornam-se indispensáveis ao historiador, já que compreende a resposta mental e emocional, seja de um indivíduo, seja de um grupo social" (THOMPSON, 1991, p. 15) ${ }^{4}$. É nessa perspectiva que se insere a figura da mulher trabalhadora rural "boiafria” enquanto possibilidade de análise.

As reflexões trazidas por este artigo ancoram-se nos estudos de gênero, uma vez que procuram compreender as interfaces das experiências de lutas e resistências de mulheres e homens que trabalham no setor rural do interior paulista. Dessa forma, entende-se que a historiografia de gênero, enquanto categoria de análise, tornou-se fecunda a partir da "década de 1970 e inícios dos anos 1980", quando privilegiou estudos acerca das "questões do trabalho feminino, em particular, o fabril". Notadamente, "a prioridade dada a esta temática se deveu a crescente presença feminina no mercado de trabalho, à importância do tema nas plataformas feministas e aos vínculos destas pesquisas com a historiografia dos movimentos de trabalhadores" (MATOS, 2013, p.6) .

No tocante a essas questões, a discussão ao longo do texto pauta-se pelas nuances presentes nas especificidades de gênero enquanto categoria analítica, dedicando atenção especial às singularidades presentes nas práticas e experiências de lutas das mulheres trabalhadoras rurais, aqui personificadas na figura de "boias-frias". Em face dessa questão,

\footnotetext{
${ }^{4} \mathrm{O}$ conceito de experiência deste autor procura abarcar as especificidades do cotidiano dos "boias-frias", que norteiam e compõem a presente trama, legitimando a experiência como ponto fundamental para se entender o aspecto da cotidianidade, saindo do geral para o particular.

${ }_{5}^{5}$ MATOS, Maria Izilda Santos de. História das mulheres e das relações de gênero: campo historiográfico, trajetórias e perspectivas. Mandrágora, v.19. n. 19, São Paulo, 2013, p.5-15.
} 
este estudo ancora-se na observação de que as usinas sucroalcooleiras alocadas no interior paulista se configuram como locais de desenvolvimento de tensões e exercício de poderes, propiciando às mulheres trabalhadoras a conquista deste espaço, mesmo quando precisam lidar com enfrentamentos e sérios empecilhos para se firmarem enquanto parte integrante dessa engrenagem contraditória que é a agroindústria.

Esses enfrentamentos aparecem nas falas das mulheres entrevistadas. Uma delas, $J_{u ́ l i a}{ }^{6}$, que veio do estado de Minas Gerais ainda com 19 anos de idade, na companhia de seus pais,foi categórica ao afirmar: "Eu sinto que meu pai foi ruim pra nói, por não dar estudo, né. O estudo fai muita falta, maieu tem eles [filhos] graças a Deus, eles escreve bem, fai bem conta, tudo queles quiser eles fai. Eu quis que les estudasse".

A entrevistada se entristece ao falar da escola, afirmando que não teve oportunidade de estudar. $\mathrm{O}$ fato de esta não ter apresentado a mesma característica de seus pais com relação à escolaridade dos filhos indica as transformações às quais o campo vem sendo submetido, sendo a presença da mecanização um degrau para as mudanças de hábitos no seio familiar dos trabalhadores rurais "boias-frias". Isso acontece mesmo tendo em vista que a escolaridade já não se torna ingrediente necessário à inserção e permanência dos trabalhadores rurais no incipiente mercado de trabalho. Entretanto, achando-se incapaz de garantir a permanência dos filhos no campo, Júlia teve a consciência de que pelo menos eles poderão ter um quesito essencial para disputar uma vaga no restrito mundo do trabalho ${ }^{7}$.

Segundo Weil (1996, p. 414), “um sistema social está profundamente doente quando um camponês trabalha a terra pensando que, se ele é camponês, é porque não era inteligente o bastante para torna-se professor". Outra particularidade que diferencia as mulheres entrevistadas é quanto à sua persistência e interesse nos estudos. Ivete, de 27 anos, dois filhos, é natural e residente na cidade de Tarumã, interior de São Paulo.

À época da pesquisa, Ivete encontrava-se na $8^{\mathrm{a}}$ série, almejando o término do Ensino Médio, o antigo colegial. Por seu turno, Carminha, de 32 anos, com uma filha de 10 anos de idade, faz questão de ressaltar que sua filha não deve sair da escola, pois não quer que tenha no futuro o mesmo destino que ela, já que considera sua função pesada e sem segurança. $O$ estudo,nesse caso, é visto como gerador de oportunidades e melhores possibilidades de trabalho, além de consistir em um importante capital social, permitindo que as trabalhadoras sejam respeitadas como mulheres e cidadãs que são.

\footnotetext{
${ }^{6}$ Os nomes dos trabalhadores apresentados nos relatos são fictícios.

${ }^{7}$ Weil (1996, p. 414) nota que tal ponto de vista perpassa "o prestígio da cultura que tem se tornado quase exclusivamente social, tanto no camponês que sonha em ter um filho professor, ou no professor que sonha ter um filho universitário, quanto nas pessoas de sociedade que bajulam os sábios e os escritores famosos".
} 
Face aos excertos apresentados acima, nota-se que a diversificação das atividades das mulheres trabalhadoras dos campos ou das cidades perpassa a prática do trabalho de cuidar da casa e dos filhos, cortar, carpir e limpar carreadores ${ }^{8}$ nas atividades da cultura canavieira, além de estudar. As dificuldades das mulheres trabalhadoras da cana iniciam-se com o encravamento dos primeiros raios solares no solo dos canaviais, submetendo-se, posteriormente, ao trabalho nas mais variadas atividades que a cana de açúcar exige. No regresso, com o término das jornadas de trabalho nas áreas delimitadas pelas usinas, encontram pela frente as atividades domésticas para serem executadas, compondo as tão conhecidas duplas, triplas, quádruplas, quíntuplas jornadas de trabalho.

Nesse contexto, uma das trabalhadoras rurais da cana, entrevistada no oeste do estado de São Paulo, destaca como era o seu cotidiano, e relembra com certa tristeza suas práticas face ao avanço do capitalismo no campo:

Era muito penoso pra mim; levantar de madrugada, o dia inteiro, pra chegar a noite inda ir fazer janta, sabe o que eu fazia... eu chegava já ia lavano as mãos, pondo janta no fogo, dano um jeito de lavá as louça, daí ia insaboá as roupa di noite; no claro da luz. Eu lavava toda a roupa, cuidava de tudim, os minino não falava: "a mãe, a senhora tá ino na roça e nói tá andano sujo, ah não". Trocava todo dia pra trabaiá e eu lavava roupa de noite [...]. Fazia comida de manhã cedo, eu levantava três horas pra fazer o almoço, a mistura, o café; fazia tudo no dia [...]. (Júlia, Tarumã-SP: 15/11/2000) ${ }^{9}$.

O trecho da entrevista com Júlia torna-se revelador para refletirmos acerca do cotidiano das mulheres trabalhadoras rurais "boias-frias", especificamente quando as incumbências destas são observadas na atuação de uma dupla jornada de trabalho: trabalhadoras rurais durante o dia; mães e donas de casa no fim das jornadas de trabalho. Além disso, algumas poucas também exercem o papel de estudante nas primeiras horas da noite.

O excerto da entrevista remonta a percepções que tangenciam a história e a memória da entrevistada ou do grupo social do qual faz parte, desvelando que "embora relacionadas entre si, vivência e memória possuem natureza distintas, devendo, assim, ser conceituadas, analisadas e trabalhadas como categorias diferentes dotadas de especificidades" (AMADO, 1995, p.131). Nessa mesma perspectiva, a autora assegura que "o vivido remete à ação, a

\footnotetext{
8 "Dá-se o nome de carreadores a todas as vias geralmente não pavimentadas, localizadas dentro ou fora de propriedades rurais, com a função de escoar a produção de uma cultura agrícola de uma determinada área".SCARPINELLA, G. D. Carreadores da cultura da cana-de-açúcar: vantagens e desvantagens do tratamento do subleito. Revista Brasileira de Ciências Ambientais. N 29, Set. 2013, p. 88. Acesso: 10 de maio de 2017.

9 A depoente revelou que era trabalhadora rural "boia-fria", porém não cortava cana. Atuava em outras atividades no eito: era "catadora de bituca" na maior parte das safras e, fora do período da colheita da cana, atuava na plantação de novas mudas ou carpindo carreadores.
} 
concretude, às experiências de um indivíduo ou grupo social", o que de certa maneira nos leva a refletir que "a prática constitui o substrato da memória, esta por meio de mecanismos variados, seleciona e reelabora componentes da experiência" (AMADO, 1995, p.131).Diante das inquietantes práticas sociais vivenciadas por homens e mulheres trabalhadores rurais,questionamos uma das entrevistadas a respeito de como ela fazia uso dos finais de semana, especialmente do domingo, um dia da semana que naturalmente o capital não exige a sua presença nas atividades laborais nos campos das usinas. Obtivemos a seguinte informação:

Eu levanto cedo, às vezes tem roupa pra lavar ainda; daí lá pelas dez horas eu vou fazer o almoço pros meninos. Daí depois eu vou fazer merenda pra semana inteira; merenda é pão, bolacha essas coisas... pra tomar café na roça; daí quando é a média de três horas eu vou descansar né. Daí seis horas tenho que ir pro fogão de novo cuzinhar. Às vezes fazer merenda também, quando não dá pra fazer. Daí tem dia... todo dia eu acordo quatro horas, mai duas, três vei por semana né, treis e meia... três e quarenta... (Carminha, Tarumã-SP: $16 / 11 / 2000){ }^{10}$

Diante das responsabilidades dos afazeres domésticos, as práticas femininas no que tange às lutas, resistências e submissão têm se evidenciado, mesmo porque esta última diz respeito aos interesses provenientes dos patrões, maridos/companheiros e, até mesmo, pais ou irmãos mais velhos. Mas, de toda sorte, as mulheres têm procurado manifestar suas indignações frente às mais diversas formas de exploração e opressão, criando "estratégias de luta e de sobrevivência mostrando resistências à dominação no âmbito do público e no privado" (MATOS; SAMARA, 1999, p. 69).

Essa afirmativa ganha relevância nas pesquisas de gênero enquanto perspectiva de análise da história das mulheres, que tem se tornado um terreno fértil para as interpretações que cercam as experiências, as práticas e representações que foram tecidas ao longo dos anos acerca dos gêneros femininos e masculinos. Provenientes de famílias muito pobres, as mulheres entrevistadas também mencionaram suas passagens pelas desilusões de casamentos que não deram certo, restando-lhes a culpa pelo fracasso e as crianças, das quais elas são encarregadas do sustento. Desse modo, suas participações, experiências e conquistas ao longo dos anos têm dado possibilidade a múltiplas visões, ocasionando vários debates a respeito de sua atuação política e social no tecer da história. Por esse viés, nota-se que "às vezes,

\footnotetext{
${ }^{10}$ Esta depoente é natural do estado de Pernambuco, tendo vindo muito cedo para o estado de São Paulo. Foi casada uma vez, ficando com uma filha que, no momento da entrevista, encontrava-se com 10 anos. Informou que estudou pouco: "Eu estudei só até o $4^{\circ}$ ano; o pai foi pobre, sabe como é que é, né; só quer mais o serviço pra ajuda a família. Então, muito e muito tempo, tinha 12 ano quando comecei a cortar cana; hoje tou com 28, e continuo, e quero ver se puxo mais uns anos ainda".
} 
indivíduos e grupos apropriam-se de vivências antigas, anteriores, experimentadas não apenas por eles ou por seus contemporâneos, mas também por antepassados, por gente que viveu antes deles, em outras épocas" (AMADO, 1995, pp.132-3).

Apesar da participação das mulheres "boias-frias" em conflitos sociais - como greves, piquetes, ocupações, enfrentamentos com contratadores ou chefes - ter ganhado expressão nas mais diversas áreas rurais do país, essas ações não puderam ser detectadas na região focalizada por essa pesquisa. Nas falas das entrevistadas do oeste paulista não emergiram informações se estas participaram de movimentos coletivos de reivindicação, greves ou motins, no âmbito das usinas de açúcar e álcool, para quem prestavam serviços. Porém, conforme Pereira (2002), essa experiência de lutas e resistências pode ser observada nas falas de outras mulheres trabalhadoras rurais "boias-frias":

No Inquérito Policial sobre a greve e nas entrevistas que fizemos com diversas mulheres que participaram da revolta, nota-se que estiveram à frente da mobilização: na organização inicial da greve no canavial, nos piquetes, na depredação da Sabesp, no saque ao supermercado, nas assembleias... e no enfrentamento com bombas, cassetetes e balas da PM. Abraçaram a greve, como o fizeram seus companheiros de trabalho do canavial, porque assim como eles, sabiam que essa era a única oportunidade de derrotar a intransigência patronal e conquistar seus direitos. (PEREIRA, 2002, p. 57, grifos nossos).

Apesar de o analfabetismo encontrar-se presente na vida das mulheres que atuam na área rural, estas procuraram incorporar às suas práticas anseios de sujeitos sociais que reconhecem seu valor e buscam instrumentos para enfrentar as desigualdades presentes no processo de transformação que emerge das exigências do capitalismo no campo. O excerto acima, mencionado por Pereira(2002),torna-se revelador por explicitar que foram as mulheres que estiveram vinculadas aos piquetes, à organização da greve e aos enfrentamentos com a Polícia Militar no interior paulista.

As depoentes do presente estudo, por seu turno, não mencionaram ter participado de conflitos nos canaviais na região de Assis, local em que se encontram as Usinas Nova América e Maracaí, nas quais são cortadoras de cana. Podemos pensar na justificativa da não expressão das tensões frente à opinião pública, uma vez que se tornou evidente que tais tensões, ocasionadas naqueles canaviais, não têm destaque nas páginas dos jornais locais.

Não obstante, as mulheres trabalhadoras "boias-frias", fora do espaço dos canaviais, revelaram suas lutas e o enfrentamento de desafios acentuados, maiores até do que lidar nas atividades rústicas da cana. Tornou-se um desafio para essas mulheres lutar contra os preconceitos, estigmas e representações sociais construídos à sua volta, uma vez que a função 
que ocupavam no âmbito das usinas as tornava, muitas vezes, invisíveis aos valores pautados por interesses de setores masculinos. Vale ressaltar que "as mulheres ainda enfrentam barreiras, ocupam os lugares menos privilegiados na economia, ganham menos do que homens e têm condições de trabalho ainda mais precárias” (BRUSCHINI, 1999, p. 44).

Essa questão é desenhada nos canaviais do oeste paulista, visto que agenciadores e formadores de eito sempre selecionam mulheres para iniciar as atividades de corte nos lugares em que a cana não possibilita uma maior produtividade, sendo ruim de se cortar. As trabalhadoras levam mais tempo para atingir a meta proposta pelos usineiros nesses espaços, o que as impede de obter um rendimento maior. Neste aspecto, podemos notar um grau de hierarquização no seio do trabalho rural, pois os lugares apropriados para a produção em maior escala são conferidos aos trabalhadores rurais do sexo masculino. As mulheres, porém, não mencionaram serem obrigadas a começarem o corte da cana nos lugares mais inóspitos. Para elas, "os homens pegam na ponta do eito porque cortam mais, então eles vão abrindo o eito". Em geral, aqueles que abrem o eito têm o "privilégio" de produzir mais, obtendo, assim, melhor remuneração, uma vez que cortam a "melhor cana" e, consequentemente, têm a maior produtividade, um dos maiores anseios das usinas em questão.

Os estudos de Saffioti (1981, p.40) apresentam a diferença salarial entre homens e mulheres como uma situação premente. A grande diferença, sinaliza a autora, ocorria no setor agrícola, em que "o alto percentual de mulheres que aparecia sem rendimentos certamente estava composto de grande contingente feminino de trabalhadoras membros não remunerados da família" (SAFFIOTI, 1981, p. 40). Essa diferença ainda existe e não foi corrigida na atualidade, apesar dos avanços alcançados.

\section{Mulheres, mecanização e corte manual da cana}

A mecanização no campo apresenta certa dualidade quanto ao processo de exclusão de homens e mulheres de suas atividades laborais ${ }^{11}$. A automação torna-se um fator concreto na ação de poupar mão de obra. Isto é fato. Neste aspecto, emerge a exclusão não somente das mulheres, mas também dos homens face ao seu concorrente - o ligeiro desempenho das máquinas modernas adquiridas pelas usinas de açúcar e álcool. Há, por outro lado, o fato de que os empresários dos setores sucroalcooleiro se esquivam de investir na formação técnica das mulheres que cortam cana, com o objetivo de lidarem com a nova tecnologia. Já uma parcela dos trabalhadores homens é treinada pelos setores responsáveis pela implementação

\footnotetext{
${ }^{11}$ Os relatos das mulheres, a imprensa e os documentos do S.T.R. não possibilitaram observar se existe a
} presença feminina realizando atividades com o uso da automação, diferentemente dos centros urbanos. 
da tecnologia no campo, no sentido de promover a sua inserção no corte da cana, antes manual e, agora, com a automação em larga escala. Na lógica do capital, cria-se uma falsa visão de que os trabalhadores excluídos do corte manual seriam gradativamente inseridos em outras atividades motivadas pela automação em determinados setores das usinas.

Assim, a área técnica do setor sucroalcooleiro não viabiliza a inserção das mulheres nesse campo, seja operando máquinas, tratores, caminhões, ou trabalhando na manutenção das mesmas. Observa-se que, no transcorrer da pesquisa, não presenciamos nenhuma mulher realizando as atividades descritas. Esse dado, de certa forma, contribui para a exclusão das mulheres dessas atividades agrícolas e possibilita novos olhares acerca dos lugares ocupados e transitados pelas mulheres trabalhadoras, especificamente pela trabalhadora rural, que vem sendo excluída dos escassos postos de trabalhos existentes tanto na zona rural, como na urbana, não só pelo processo da automação, mas pela prática de exclusão proveniente de interesses exclusivamente masculinos. Em geral, as mulheres trabalhadoras "boias-frias" não chegam a ocupar posições privilegiadas nas áreas rurais, com exceção das atividades de "descarte" $" 12$ da cana.

As tarefas do descarte referem-se ao reconhecimento das doenças, sua classificação e recuperação da planta através da retirada das partes afetadas descarte - e da aplicação de agrotóxicos. As assim chamadas 'meninas' são selecionadas pelos técnicos e fiscais, devendo possuir um certo grau de escolaridade, pois a tarefa exige que as doenças sejam anotadas e contadas.(SILVA, 1997, p. 565).

Esse lugar,notadamente,não é conferido aos homens, nem a todas as mulheres trabalhadoras, já que algumas mulheres que não apresentam certa habilidade e manejo para tal atividade. Por outro lado, isso não significa que as mulheres estejam sendo valorizadas e respeitadas enquanto profissionais. Observamos que, em sua maioria, os homens trabalhadores rurais "boias-frias" não apresentam o perfil necessário exigido pelos usineiros para essa atividade: a sensibilidade, o manejo para lidar com a doença da cana e, em muitos casos, a escolaridade, elemento que também faz a diferença no momento de conferir essa atribuição às mulheres.

$\mathrm{Na}$ tessitura dessas reflexões, destacamos o trabalho pioneiro de estudos de gênero da pesquisadora Saffioti (1981). Segundo Matos (2013, p.6), a autora se propõe a discutir "os signos da opressão masculina e capitalista sobre as mulheres centrada na teoria do patriarcado". Saffioti (1981, p.21) sinaliza que a sensibilidade feminina estaria associada à

\footnotetext{
${ }^{12}$ A palavra descarte, segundo o Dicionário Aurélio, significa o ato de descartar algo que não presta. Neste contexto, o significado de descartar é mais amplo, representando uma repercussão maior. Um ato um tanto quanto excludente, uma vez que não possibilita a entrada de outras mulheres, nem de homens.
} 
"sofisticação tecnológica da indústria que tem minado, grandemente, a ideologia de que a mulher apresenta mais habilidade manual para o desempenho de tarefas minuciosas, do tipo das que têm lugar em indústrias têxteis de baixa densidade de capital"13.

No contexto das trabalhadoras rurais da cana, inúmeros depoimentos de fiscais, técnicos, feitores e das próprias mulheres trabalhadoras rurais que atuavam nessa prática foram observados. "Feitores e técnicos são unânimes em afirmar que o descarte só é desempenhado pelas mulheres, porque elas são responsáveis, obedientes, e os homens não. Todas as tentativas com os homens nessa atividade fracassaram" (SILVA, 1997, p. 565, grifo nosso). Podemos notar que não foi uma opção pelo trabalho feminino, mas uma demanda do capital e do agronegócio, uma vez que alguns homens não dispunham da habilidade necessária à função designada. A responsabilidade dessas mulheres se torna visível ao verificarmos que se trata de uma atividade que requer o máximo de atenção possível. A cana não poderia ocupar o solo com algum tipo de ameaça e as doenças precisam ser catalogadas e curadas pelas "meninas do descarte".

De acordo com essas reflexões, nas falas dos responsáveis pela dinamização do trabalho nos canaviais, a presença da mulher é vista como sinônimo de passividade. A obediência foi notada, nessa análise, como uma "submissão" a algo que os homens não se sujeitam, pelo menos em algumas situações.

Essa prática utilizada nos canaviais do interior paulista busca também hierarquizar e separar os trabalhadores do campo, inclusive as mulheres, propiciando o desencadeamento de mais conflitos entre elas. A causa mais comum tem relação com o fato de essas "meninas do descarte" serem consideradas uma categoria superior entre as "mulheres trabalhadoras boiasfrias", uma vez que, além de receberem salários um pouco maiores, são consideradas qualificadas para tal atividade. Muitas recebem prêmios por produção e são, ainda, “convidadas a passarem temporadas em alojamentos da usina em regiões litorâneas", o que não acontece com as demais mulheres que atuam no corte da cana (SILVA, 1997) ${ }^{14}$.

Por esse prisma, o tipo de contratação das mulheres que atuam no corte da cana tornase representativo para refletirmos sobre suas práticas nos canaviais dos territórios das usinas em questão, especificamente nos períodos de safras e de entressafras das culturas agrícolas, particularmente, a canavieira. Durante o trabalho de campo, cujo objetivo era realizar as

\footnotetext{
${ }^{13}$ SAFFIOTI, Heleieth I. B. Do artesanal ao industrial: a exploração da mulher. Um estudo de operárias têxteis e de confecções no Brasil e nos Estados Unidos. São Paulo, HUCITEC, 1981.

${ }^{14}$ Sobre à lógica do capital no século XIX, Thompson (1998, p.297) destaca que tal prática esteve associada à "divisão do trabalho, a supervisão do trabalho [...], incentivos em dinheiro, pregações e ensino, supressão das feiras e dos esportes - formando-se novos hábitos de trabalho e imposição a uma nova disciplina de tempo".
} 
entrevistas junto dos trabalhadores rurais da região de Assis (SP), notou-se crescente diminuição do número de mulheres nas turmas de trabalhadores rurais. $\mathrm{Na}$ época da pesquisa (setembro, outubro e novembro de 2000; maio e junho de 2001) tivemos acesso a várias turmas de trabalhadores, sendo a presença feminina sempre muito reduzida em relação aos homens. Do ponto de vista estatístico, podemos afirmar que a presença feminina era quase inexistente em algumas dessas turmas de trabalhadores rurais cognominados de "boias-frias".

Durante o contato com os primeiros trabalhadores, questionamos: por que existem tão poucas mulheres nesta atividade e por que existem turmas de trabalhadores em que não há nenhuma mulher? Em sua maioria, os homens entrevistados responderam "as mulheres não aguentam o serviço"; "ficaram em casa cuidando dos filhos pequenos", enquanto outros enfatizaram que não permitiam a presença das esposas no meio de outros homens. Percebemos que a prática do trabalho nos canaviais é considerada, por muitos homens, uma forma de trabalho inadequada para suas esposas, que são mulheres "direitas".

Fica evidente, nesse caso,certo machismo pautado na prática da hierarquização masculina, com o intuito de direcionar os passos de suas companheiras ou mulheres sob a sua tutela. A questão posta não possibilita pensar essa atitude como uma decisão de proteger a mulher do trabalho cansativo e monótono da cana. Percebemos, ao longo das falas dos depoentes masculinos, certo preconceito implícito e explícito, além de uma dominação exacerbada. Assim, a maioria das mulheres que trabalham na cana é associada a separação conjugal e a situações monoparentais, criando e reforçando estigmas que segregam a vida das trabalhadoras rurais. A profissão de mulher "boia-fria" é vista, pelos próprios atuantes nesse trabalho, como inconciliável à tarefa de esposa, dona de casa e mãe de família.

Uma das questões mais evidentes nos relatos é o medo de falar e de opinar a respeito das condições de trabalho a que foram submetidas. Nas fazendas onde se executa a prática do corte da cana, as mulheres que atuam nesta atividade ficam totalmente encobertas por vestimentas escuras, sujas de fuligens da palha da cana queimada. Vestem botas, perneiras de aço, luvas de couro de boi, calças jeans, camisas de mangas compridas, "mangotes" por cima da blusa, lenço amarrado na cabeça, transpassando a boca e parte do rosto, além do chapéu de palha sobre a cabeça, para se protegerem do calor do sol - prática, aliás, que se verifica em todas as atividades envolvendo o serviço da cana.

A forma pela qual as trabalhadoras rurais se vestiam para atuarem nos canaviais nos possibilitou pensar que o trabalho na cana era composto apenas de integrantes do gênero masculino. Entretanto, ao observarmos os trabalhadores no momento em que paravam para descansar e realizar a refeição, percebemos que as mulheres começavam a "surgir". Elas 
retiravam de seu corpo a maioria dos apetrechos utilizados para suportar as insalubridades oferecidas pela forma de trabalho do canavial e, pouco a pouco, assumiam sua feminilidade. As luvas de couro de boi cediam lugar à rusticidade das mãos devida ao trabalho pesado da área rural. As mulheres não escondiam o desejo de terem mãos lisas e as unhas feitas, práticas de higiene e cuidados percebidas e realizadas por outras mulheres que não atuam nessas atividades, na maioria das vezes originárias de áreas urbanas. Ao se livrarem das rústicas luvas, deixavam aparecer, de forma tímida, as unhas trabalhadas e pintadas. Os cabelos, lisos ou encaracolados, saíam por baixo dos lenços escuros e das abas dos chapéus. O fato de se desprenderem das perneiras de aço, utilizadas para a prevenção contra acidentes graves, também expressa certo ar de liberdade face ao gênero masculino, uma vez que se torna impossível identificar quem é homem ou mulher nas condições acima descritas. Esse processo de metamorfose das mulheres do canavial do interior paulista exemplifica sua presença no campo da produção de alimentos e gêneros agrícolas.

O uso de todos esses apetrechos, cotidianamente, traz à luz certa preocupação das mulheres com a proteção de seus corpos, uma vez que esse tipo de trabalho apresenta um dos mais altos níveis de rusticidade. É exigida a constante repetição desses hábitos nas mais variadas atividades no espaço em que se desenvolve a agricultura brasileira.

\section{Contrato de trabalho temporário nas usinas}

Com base nas falas de outros trabalhadores, podemos dizer que a definição das atividades acontece da seguinte forma: inicialmente o candidato é escolhido pelo agenciador para exercer uma atividade no canavial, ou melhor, pleitear uma possível vaga de contrato temporário enquanto cortador de cana. No primeiro dia, o candidato terá que cortar a média de sete toneladas de cana e, realizando essa média, poderá ser contratado.

Durante a primeira semana, o novo trabalhador fica sob os olhares do agenciador, que verifica o seu desempenho na produção. Em alguns dias da semana pode até realizar menos que sete toneladas, desde que, em outros dias, consiga recuperar a perda do dia anterior.

O outro tipo de contrato, que engloba a possibilidade de trabalhar na diária não cortando cana, mas realizando outras atividades, possui maior competitividade. Muitas mulheres e muitos homens que não conseguem fazer a média exigida pela usina são destinados aos poucos cargos que restam nas atividades agrícolas: "catar bitucas", "plantar 
pequenas árvores", "localizar formigueiros", "trabalhar nas atividades de limpar carreadores", "semear e plantar novas mudas de cana" (MATOS, 2002, p. 57) ${ }^{15}$.

Neste aspecto, possibilidades se abrem para compreendermos as mais diversas interfaces dos contratos no mundo do trabalho rural, uma vez que a produção e a força física tornam-se ingredientes indispensáveis no momento da contratação de mulheres e homens para atuarem nas mais diversas atividades no setor sucroalcooleiro. Este fator não reflete uma característica particular do setor agrário, pois se encontra também associado ao sistema de produção dos centros urbanos.Para o agenciador Aurélio,que recruta trabalhadores rurais para a U.N.A, "o contrato dá-se temporariamente, dependendo das variações climáticas. Tem ano que a safra da cana antecede-se um pouco e tem ano que a safra atrasa um pouco" (Aurélio, Tarumã-SP: $13 / 10 / 2000)^{16}$.

As mulheres entrevistadas não comentaram o tipo de contrato. Segundo elas, o contrato seria algo um pouco complicado de se entender. Observamos que outros fatores de cunho repressivo teriam inviabilizado suas reflexões acerca dos contratos, até mesmo pelo fato de poucas mulheres atuarem nas turmas de cortadores de cana. Para elas, "o Aurélio é muito bom, ele deixa nós trabalhar com os outros homens na mesma turma" (Carminha $e$ Ivete. Tarumã-SP, 02/11/2000).

As falas das trabalhadoras rurais corroboram as falas dos agenciadores dos laranjais entrevistados por Silva (1999, p. 566), no momento em que estes ressaltavam "que as mulheres são mais fáceis de lidar", o que as diferenciava dos homens trabalhadores rurais “boias-frias". É possível que tal passividade esteja associada ao limitado espaço ocupado pelas mulheres trabalhadoras nesse campo de produção. Face a essa questão, os referenciais teóricos indicam que isso ocorreu não porque as mulheres não queriam trabalhar, mas porque o sistema produtivo não lhes possibilita a inserção, devido à sua produtividade ser inferior à dos homens. Na região de Assis, as falas das mulheres enalteceram também a figura do contratador, pontuando com precisão sua solidariedade e bondade ao "permitir" que trabalhassem "ao lado dos homens", o que para elas já era percebido como um favor. Na lógica do capital, que gerencia o agronegócio no campo, a presença de pessoas oriundas de

\footnotetext{
${ }^{15}$ Matos evidencia os tipos de trabalhos eventuais surgidos nos momentos de crise no início do século XX. Ressalta que esse tipo de trabalho, visto como informal, traduz as diferentes práticas de atividades até então realizadas, tais como: "jardineiro, capinador, lavador, encerador, desentupidor, limpador de calhas, podador de árvores, exterminador de formigas". Observa-se que tais atividades chegavam a ser "remuneradas com um prato de comida, em outros casos, era realizado como complementação salarial” (p. 57).

${ }^{16}$ Aurélio é responsável pela contratação de uma turma de 60 pessoas, sendo 6 do sexo feminino e os demais do sexo masculino. No que tange ao tipo de contratação, este foi categórico na afirmação de contratos temporários de mulheres e homens, sinalizando que sua comissão por cada pessoa representava $14 \%$ de sua produção.
} 
setores segregados (mulheres) no complexo mundo do trabalho deixa de ser um direito para se tornar um favor.

Ao mesmo tempo em que se confirmam práticas de submissão feminina nos canaviais e nos laranjais do estado de São Paulo, por outro prisma, em alguns momentos, as mulheres libertam-se dapressão exercida pelos contratadores/agenciadores e buscam reaver seus direitos e sua cidadania, mesmo que forçadas juridicamente, propiciando certos enfrentamentos. Um fato exemplar é um trecho do depoimento de Júlia, para quem encaminhamos a seguinte pergunta: a senhora já moveu alguma ação judicial contra alguma das usinas pertencentes ao Grupo Nova América?

Eu vou falar a verdade, eu não gosto de mentira, eu levei a Nova América em processo; sabe porque é queu levei, eu vou contar direitim pra você. Então, eles, eles me tirava do serviço falando que eu tava apusentada e mim dero ai fui pra recebê, eles me dero aquele salaro disemprego. Chegou lá no sindicato, eles rasgaro. Eu falei bom, não tem importância, dispoi eles falou assim: "daqui a um mei a senhora vai receber setecentos reais", eu falei, eu num venho. Já falei quando peguei o pagamento na mão, não venho mai. Eu nem venho aqui e nem vou na Usina eu já achei que é pouco pagamento dois mil e seicentos. Daí eu falei assim: lá é muito pouco; as férias metade de um décimo tercero, mai uma quinzena minha, eu acho qué pouco, com treze ano de trabaio, daí eles falou "dona Júlia, não é pouco não que a senhora aposentou..." pagano dois e seicentos com tudo isso. Mai eu acho que eu tinha razão; daí eu peguei fui no sindicato, o sindicato: "não dona Júlia, o que é certo é certo, a senhora ainda tem direito e mai", eu fui no sindicato, tirar um parecer sabe. Daí eu falei assim: o que o senhor acha, ele falou: "ainda tem uns troco lá ainda"; mai eu fui no advogado, o devogado fei a conta de tudo queu trabalhei; e disse: "a senhora tem, a senhora tem direito a cinco mil pra trai". Daí eu falei bom, nem que não seja isso; [...] mai seno, o qui ficou meu é meu. Falei assim: com ele; o rapai do sindicato falou: "tá certo", eu não vou brigá com eles, eu só quero o que é meu. Falei pra muler que fei o pagamento pra mim lá no foro, eu falei "ah, eu não vou voltá na Usina e nem vou voltá aqui mais". Agora saiu, eu recebi maitrei mil e seicento; eu recebi no foro. Fez quatro ano agora [...] no dia treze de dezembro fai quatro ano. Vai fazer quatro ano; daí eu ponhei eles me pagaro eu aceitei a proposta queles fizero, chamou eu no acordo lá, se eu concordava, vim receber imtrei parcelas, trei mil e seicentos. (Júlia, Tarumã-SP, 15/11/2000, grifos nossos) ${ }^{17}$.

É necessário assinalarmos o depoimento integral de Júlia no que se refere a essa questão, reportando-se a ações judiciais impetradas contra as usinas sucroalcooleiras pertencentes ao Grupo Nova América. A riqueza e o detalhamento das informações existentes neste depoimento estão além das representações da depoente a respeito das pretensões do

\footnotetext{
${ }^{17}$ No momento da entrevista, Júlia apresentava-se com 57 anos, aposentada por tempo de serviço (uma raridade entre as mulheres 'boias-frias') e residia com o segundo marido numa casa de COHAB na cidade de Tarumã, interior de SP.
} 
agronegócio. Tal observação sinaliza a ideia de não passividade e não submissão generalizada da mulher trabalhadora cognominada de "boia-fria" no oeste paulista.

Em sua fala, revela-se a tessitura do transcorrer do processo na esfera jurídica, descortinando a singularidade da não submissão desta mulher, que merece destaque dentro do conjunto das entrevistadas. Ao tecer as considerações a respeito da ação feminina, chamamos a atenção também para o fato de que o objetivo não é segregar o gênero feminino, mas assinalar como essas mulheres, em vários momentos de suas vidas, conseguiram perceber o grau de exploração a que foram/são submetidas, buscando, consequentemente, a mudança desta situação. Chama a atenção o fato de que "a presença feminina no mercado de trabalho informal é indicativo de que, apesar dos limites impostos, as mulheres desenvolveram estratégias próprias de sobreviver nessa sociedade" (MATOS, 1999, p. 58).

O relato deixa evidente que o grau de escolaridade de Júlia era inexistente. Porém, suas experiências e lutas constroem e reconstroem uma prática, tornando-a liberta de múltiplas opressões oriundas dos desmandos do capital no campo. Esta depoente informou, em outro momento da conversa, que só para a U.N.A. "havia trabalhado 13 anos". A percepção da quantia em valores que deveria receber por 13 anos de trabalho ficou explícita na fala de Júlia desde o início. Júlia contou sobre sua trajetória entre o Sindicato Rural de Assis e a Usina Nova América, questionando a pouca quantia que teria recebido pelos seus 13 anos de trabalho depositados nesta empresa.

Vemos que, nesse caso, o sindicato deu um parecer de que a entrevistada teria em haver uma quantia pequena, algo irrisório. Na reprodução da fala do representante do Sindicato pela depoente, ficou explícito certo descaso: "você tem em haver uns trocos".

Já na fala do advogado, definiu-se uma quantia de aproximadamente $\mathrm{R} \$ 5.000,00$, valor que, para a depoente, era bastante, uma quantia condizente com seus 13 anos de trabalho. Observamos que o advogado não era gratuito, não sendo um serviço oferecido pelo Sindicato. Ainda que a depoente tenha dito, em um primeiro momento, que quem desvendou o processo fora o advogado da usina, a mesma pontuou que o advogado cobrara $\mathrm{R} \$ 2.100,00$ pelas despesas e honorários gastos.

Acredita-se que este advogado tenha sido recomendado pelo Sindicato. Esse profissional particular teria informado Júlia sobre seus direitos, uma vez que não faz sentido um advogado da própria empresa defender os interesses dos trabalhadores. Acrescentamos a isso a fala da depoente, segundo a qual os valores haviam sido pagos no Fórum da Comarca de Assis (SP) e haviam sido negados no momento de sua dispensa. A busca de haveres pela depoente deu-se após sua aposentadoria ter sido homologada pelo INSS. 
Ao final de sua argumentação, a depoente revela certa "passividade" por parte dos usineiros ao aceitarem sua reivindicação junto à Justiça do Trabalho, notando-se que o direito do trabalhador era negado anteriormente pelo usineiro. A entrevistada manifesta a sua indignação com a pouca quantia que havia recebido de seus patrões (usineiros), deixando explícito um certo poder de barganha com o usineiro local, já que ela não necessitava de emprego nas colheitas futuras de cana, uma vez que teria sua aposentadoria já assegurada.

Com base no depoimento de Júlia, podemos observar que, num primeiro momento, ela não havia discutido com os donos da usina pela quantia que lhe teriam pago. Em um segundo momento, ela queria ter em suas mãos alguma parte do que lhe era de direito. Somente posteriormente, procurou a Justiça trabalhista, a fim de confirmar se realmente estava correto o que lhe haviam pago pelo seu tempo de serviço. Desta forma,

Ao trazer o passado até o presente, recria o passado, ao mesmo tempo em que o projeta no futuro; graças a essa capacidade da memória de transitar livremente entre os diversos tempos, é que o passado se trona verdadeiramente passado, e o futuro, futuro, isto é: dessa capacidade da memória brota a consciência que nós, humanos, temos do tempo (AMADO, 1995, p.132).

Com destreza, a fala da depoente explicita a ideia de uma consciência: a de quem estava sendo lesada pelo usineiro, manifestando o desejo de não prejudicar o seu patrão, mas, por outro lado, o desejo de não ficar lesada e oprimida pelas práticas dos usineiros naquela região. O relato de Júlia revelou uma prática que atinge centenas de trabalhadores brasileiros, no momento em que são dispensados de suas funções trabalhistas e buscam reaver seus direitos, sejam estes provenientes do campo ou da cidade.

Chamam a atenção também as atitudes opostas adotadas pelos trabalhadores rurais "boias-frias" da Alta Sorocabana (oeste paulista) e os da cidade de Campinas, também interior do estado.

\begin{abstract}
Alguns assumem a miséria inevitável e tentam combatê-la competindo com os companheiros, enquanto outros chegam a lutar contra os fazendeiros pela posse da terra, enfrentando capangas e só desistindo perante a força policial, ao mesmo tempo em que exprimem sua decepção [...]. Os "boias-frias" da região de Campinas só se sentem concernidos pelas eleições locais, quando dispõem de certo poder de barganha com os poderosos do lugar, mas não se interessam pelas eleições nacionais, visto que têm clara consciência de estarem excluídos das decisões de um poder mais amplo. (CHAUÍ, 2000, p. 53, grifos nossos).
\end{abstract}

A autora assinala que existe uma diferença entre as práticas dos "boias-frias" das duas regiões analisadas, indo de encontro à fala de Júlia. Ao mesmo tempo em decide lutar contra o usineiro junto à Justiça do Trabalho, apresenta certa liberdade para negociar com os 
usineiros. Isso pode ser observado, principalmente, pelo fato de Júlia procurar a Justiça do Trabalho após a homologação de sua aposentadoria, justamente por se encontrar livre das ameaças que poderiam migrar do setor de Recursos Humanos da usina.

Quanto aos trabalhadores rurais da cidade de Campinas, observamos seu poder de negociar com os políticos da região, exigindo e reivindicando direitos em troca do voto, o que seria vantajoso para aquele grupo de poderosos. Dependem apenas da "generosidade" 18 dos usineiros e fazendeiros em mantê-los ocupados, uma vez que a exclusão se faz presente não só no campo, mas também nas áreas urbanas de todo o país.

\section{Considerações finais}

Sem a pretensão de concluir as análises acerca das experiências de lutas das mulheres trabalhadoras rurais cognominadas de "boias-frias", este artigo buscou problematizar algumas das interfaces que evidenciam a sua luta contra a segregação e o sexismo, presentes nas áreas rurais das usinas em questão. Os relatos das mulheres trabalhadoras corroboraram as interpretações de Saffioti (1982, p. 139), ao sinalizar que "o trabalho constitui fonte de segurança e eleva a autoestima, mas a mulher está, muitas vezes, pronta a abandoná-lo em troca da posição de dona de casa, esposa e mãe”. Segundo a autora, torna-se cada vez mais difícil "a sociedade liberar do serviço doméstico uma força de trabalho excessiva para as necessidades do capital".

Nesse ínterim, foi utilizada a História Oral enquanto fonte histórica, tornando possível mapearmos, no território rural, experiências de lutas e tensões em que o feminino e o masculino se intercruzam, às vezes dialogando, às vezes se distanciando, por razões claramente excludentes. A partir das "contraprovas e análises" documentais, encontrou-se "pistas e informações preciosas, muitas inéditas, impossíveis de serem obtidas de outro modo" (AMADO, 1995, p.134). De certa maneira, esse fato permitiu nortear algumas de suas práticas de trabalho na região oeste do estado de São Paulo, na tentativa de desvelar embates, mudanças e permanências no cotidiano das mulheres, enquanto trabalhadoras, mães, esposas, domésticas e estudantes, experiências que estão muito além do cognome de mulheres "boiasfrias”. Nesse sentido, “a dimensão simbólica das entrevistas não lança luz diretamente sobre os fatos, mas permite aos historiadores rastrear as trajetórias inconscientes das lembranças e associações de lembranças [...]" (AMADO, 1995, p.135).

\footnotetext{
${ }^{18}$ A questão da generosidade neste trabalho efetiva-se quando um agenciador contrata um jovem ou um velho para trabalhar; quando este apresenta certa simpatia pelo trabalho realizado pelo seu contratado ou, até mesmo, quando o "usineiro reconhece que errou". Esta é a fala de Júlia: pagou o que devia e ficou tudo certo.
} 
Por outro viés, a pesquisa apropriou-se da perspectiva de gênero enquanto categoria de análise, com o intuito de problematizar as experiências relatadas por mulheres trabalhadoras rurais. Um aspecto que se revelou instigante neste trabalho, especificamente, foi o fato de estas trabalhadoras rurais estarem em número muito reduzido nas turmas de cortadores de cana nas usinas pesquisadas.

Nesse sentido, destacamos que a pesquisa em questão não revelou se as mulheres trabalhadoras rurais "boias-frias" trabalharam, em algum momento, conduzindo maquinários da lavoura canavieira, ou se houve alguma tentativa dos administradores das usinas no sentido de incorporá-las na condução de equipamentos tecnológicos nos parques sucroalcooleiros. Entretanto, a pesquisa revelou que, em alguns momentos das safras de cana, parte dessas mulheres pôde vivenciar a experiência de ser valorizada profissionalmente em atividades que somente elas dispunham de habilidades para realizar.

Não obstante, Matos (2013, p.11) explicita a necessidade de trabalhos acadêmicos nessa direção, pois, segundo autora, "as pesquisas nesta temática podem dinamizar as conexões entre história passada e prática atual, contribuindo para difundir que as construções/relações de gênero não são inertes, mas mutáveis e reconstruíveis".

\section{Referências}

AMADO, J. Usos e Abusos da História Oral.Rio de Janeiro: FGV, 1996.

O grande mentiroso: tradição, veracidade e imaginação em história oral. In: História, São Paulo, 1995, pp.125-136.

BRUSCHINI, C. Mudanças e Persistências no trabalho feminino (Brasil, 1985-1995). In: SAMARA, E. M. (Org.). Trabalho Feminino e Cidadania. São Paulo: Humanitas/FFLCHUSP-SP, 1999.p. 29-55.

CHAUÍ, M. S. Cultura e Democracia: discurso competente e outras falas. 8. ed. São Paulo: Cortez, 2000.

FERREIRA, M. M.; DELGADO, L. A. N. (Orgs.). História do Tempo Presente. Rio de Janeiro: FGV, 2014.

JANOTTI, M. L. M. História Oral: uma utopia? Revista Brasileira de História, São Paulo: Marco Zero/ANPUH, Vol. 13, n 25/26, 1993, pp. 7-16.

MATOS, M. I. S. de. História das mulheres e das relações de gênero: campo historiográfico, trajetórias e perspectivas. Mandrágora, v.19. n. 19, São Paulo, 2013, p.5-15.

Cotidiano e Cultura: história, cidade e trabalho. Bauru: EDUSC, 2002. 
; SAMARA, E. M. Cotidiano e trabalho feminino (1890-1940). In: SAMARA, E. M. (Org.). Trabalho Feminino e Cidadania. São Paulo: Humanitas/FFLCH-USP-SP, 1999.p. 57-71.

MONTENEGRO, A. T. História Oral e Memória: a cultura popular revisitada. São Paulo: $3^{\mathrm{a}}$ ed., Contexto, 1994.

PEREIRA, M. D. C. T.A greve dos boias-frias de Guariba e a repressão (Maio de 1984). 2002. Dissertação (Mestrado em História) - USP/FFLCH, São Paulo, 2002.

PLANCHEREL, A. A.; BERTOLDO, E. (Orgs.). Trabalho e Capitalismo Contemporâneo. Maceió: Edufal, 2011.

PORTELLI, A. Tentando Aprender um Pouquinho: algumas reflexões sobre a ética na História oral. In: Projeto História. São Paulo: EDUC, 1997, pp. 13-49.

SAFFIOTI, H. I. B. Do artesanal ao industrial: a exploração da mulher. Um estudo de operárias têxteis e de confecções no Brasil e nos Estados Unidos. São Paulo, HUCITEC, 1981.

SILVA, M. A. M. De Colono a "boia-fria". In: DEL PRIORY, M. (Org.). História das Mulheres no Brasil. São Paulo: Contexto/Ed.Unesp, 1997.

Errantes do fim do século. São Paulo, EDUNESP, 1999.

SCOTT, Joan. Gênero: uma categoria útil de análise histórica. Revista Educação e Realidade. Porto Alegre: UFRGS, 1990.

SCARPINELLA, G. D. Carreadores da cultura da cana-de-açúcar: vantagens e desvantagens do tratamento do subleito. Revista Brasileira de Ciências Ambientais. n. 29, Set. 2013.

THOMPSON, E.P. A miséria da teoria. Rio de Janeiro, Zahar, 1981.

Costumes em Comum. Estudo sobre a cultura Popular tradicional. São Paulo: Companhia das Letras, 1998.

THOMSON, A. Recompondo a Memória: questões sobre a relação entre a história oral e as memórias. In: Projeto História. São Paulo: EDUC, 1997, pp. 51-84.

WEIL, S. A condição operária e outros estudos sobre a opressão. 2. ed. Rio de Janeiro: Paz e Terra, 1996.

ARTIGO ENVIADO EM: 01/03/2017

ARTIGO ACEITO PARA PUBLICAÇÃO EM: 03/06/2017 